\title{
Minyak Atsiri Sereh Wangi Sebagai Bahan Insektisida Pada Arsip
}

\author{
Fransiska Dian Ekarini, Sri Wahyuni, Rifqi Kurniadi Suryanto, \\ Rohmad Junaedi \\ Balai Konservasi Borobudur \\ fransiscadian79@gmail.com
}

\begin{abstract}
ABSTRAK
Latar belakang kajian efektivitas minyak atsiri sereh wangi sebagai bahan insektisida pada cagar budaya berbahan kertas ini adalah banyaknya arsip dokumen terutama dari kertas yang seringkali rusak dimakan hewan perusak kertas di tempat penyimpanan arsip dokumen. Kajian ini memakai bahan insektisida alami yaitu dari tanaman sereh wangi yang ramah terhadap manusia dan lingkungan. Tujuan kajian ini adalah untuk mengetahui efektivitas minyak atsiri sereh wangi dalam mencegah dan mematikan serangan rayap kayu kering yang menyerang dokumen arsip kertas. Metode kajian yang digunakan adalah percobaan skala laboratorium. Bahan yang digunakan adalah minyak atsiri sereh wangi dan hewan uji berupa rayap kayu kering. Percobaan yang dilakukan meliputi percobaan efektivitas minyak atsiri sereh wangi sebagai bahan repellent/pengusir rayap, percobaan sebagai bahan insektisida rayap dan percobaan dampak minyak atsiri sereh wangi terhadap arsip dokumen kertas. Dari hasil kajian dapat disimpulkan bahwa minyak atsiri dapat berfungsi sebagai bahan pengusir dan insektisida bagi rayap kayu kering. Minyak atsiri sereh wangi efektif sebagai pengusir rayap kayu kering pada konsentrasi $85,9 \mathrm{mg} / \mathrm{l}$. Efektifitas minyak atsiri sereh wangi sebagai bahan insektisida rayap kayu kering dinyatakan dengan LC 50 yaitu pada konsentrasi $101,7 \mathrm{mg} / \mathrm{l}$. selain itu tidak terdapat perubahan warna secara visual pada kertas/dokumen akibat bau/aroma minyak atsiri sereh wangi
\end{abstract}

Kata Kunci: minyak atsiri, sereh wangi, insektisida, dokumen kertas

\section{ABSTRACT}

The background of the study of the effectiveness of citronella essential oils as an insecticide in this cultural heritage made from paper is the large number of document archives, especially from paper that is often damaged by insects in the archive storage. This study uses natural insecticides, namely citronella plants that are friendly to humans and the environment. While the aim of this research is to find out the effectiveness of citronella essential oil to preventing and killing dry wood termite attacks paper archival. The research method used is laboratory scale testing. The ingredients used are citronella essential oils and dry wood termites. The tests included testing the effectiveness of citronella essential oils termite repellents, testing as an insecticide and testing the impact of wood termites. The tests included testing the effectiveness of citronella essential oils on paper documents. The results of the study can be concluded that essential oils can useful as repellent material and insecticides for dry wood termites. Citronella essential oils is effective as a repellent at a concentration of $85.9 \mathrm{mg} / \mathrm{l}$. The effectiveness of Citronella essential oils as an insecticide for dry wood termites is stated with LC 50 at a concentration of $101.7 \mathrm{mg} / \mathrm{l}$. There is no visual change in color on paper document due to the smell/evaporation of citronella essential oil.

Keywords: essential oils, citronella, insecticide, paper documents 


\section{PENDAHULUAN}

\section{Latar Belakang}

Benda cagar budaya berbahan kertas sangat rawan sekali untuk rusak karena dimakan serangga. Buku terbuat dari berbagai macam bahan organik yaitu kertas, kulit, tekstil dan perekat yang mengandung pati. Bahan-bahan tersebut menarik berbagai jenis biota (serangga, hama dan organisme perusak lainnya) untuk datang. Kelompok biota yang sering ditemukan di lingkungan pepustakaan adalah serangga, tungau, tikus dan jamur mikro (kapang). Jenis serangga yang sering ditemukan di lingkungan perpustakaan dan bangunan lainnya adalah silver fish, book lice (psocid), book worm (book borer), kecoa, ngengat (clothes moth) dan rayap.

Dampak kerusakan yang disebabkan oleh serangan serangga pada material berbahan kertas antara lain adalah sampul buku yang rusak akibat kecoa yang mencompang-campingkan sampul bagian pinggir hingga ke punggung buku akibat rahangnya yang kuat. Serangga silver fish biasa memakan kertas dan cover dengan kerusakan atau lubang yang acak dan tidak merata. Rayap merupakan serangga yang paling sering dapat kita lihat dan temui, memakan dan menghancurkan koleksi hingga habis. Arsip yang dimiliki oleh Balai Konservasi Borobudur telah menjadi Memory of the World atau daftar ingatan dunia yang harus dipelihara dan dijaga kelestariannya. Cara pencegahan serangga pada koleksi cagar budaya berbahan kertas yang akan dilakukan pada kajian ini adalah dengan melakukan percobaan menggunakan minyak atsiri sereh wangi. Penggunaan minyak atsiri sereh wangi ini untuk konservasi cagar budaya berbahan kertas terutama sebagai bahan pencegah serangan serangga adalah berusaha menggunakan bahan-bahan alami yang ada di sekitar kita dan mulai beralih dari penggunaan bahan kimia yang tidak ramah lingkungan.

Bahan tradisional tembakau, cengkeh dan pelepah pisang yang telah dilakukan masyarakat Kudus dan telah diuji secara scientifik, efektif sebagai bahan konservasi kayu (Cahyandaru dkk, 2010). Penggunaan bahan tradisional tersebut terbukti secara laboratorium dan lapangan efektif untuk mencegah kerusakan kayu yang disebabkan oleh serangga perusak kayu khususnya jamur dan rayap.

Bahan tradisional lain yang bisa dikembangkan salah satunya adalah sereh wangi. Ekstrak daun sereh wangi bersifat racun terhadap cendawan/jamur (Utami 2004). Sereh wangi juga dapat digunakan sebagai insektisida alami karena kandungan sitronelal dan geraniol merupakan bahan aktif yang tidak disukai dan sangat dihindari oleh serangga (Mardani dkk, 2013). Abu dari daun dan tangkai sereh wangi mengandung 45\% silika yang dapat menyebabkan desikasi (keluarnya cairan tubuh secara terus menerus) pada kulit serangga sehingga serangga akan mati kekeringan (Mardani dkk, 2013).l

Penggunaan bahan tradisional minyak atsiri sereh wangi telah diketahui efektif sebagai bahan konservasi kayu dengan bahan tradisional (Leliek dkk, 2014). Penggunaan bahan minyak atsiri sereh wangi efektif menghambat pertumbuhan jamur pada kayu dan sereh wangi konsentrasi 3\% dapat menghambat serangan rayap dan jamur pada kayu.

Kayu merupakan bahan organik yang tersusun atas selulosa, hemisellosa dan lignin. Begitupula dengan kertas terbuat dari serat selulosa yang umumnya berasal dari tumbuh-tumbuhan seperti kayu, bambu, merang dan kapas. Kertas yang memiliki kandungan selulosa yang murni biasanya memiliki daya tahan yang lama karena termasuk senyawa yang stabil sedangkan selulosa yang tidak murni masih mengandung lignin dan hemiselulosa memiliki daya tahan yang lebih rendah. (Razak dkk, 1995).

Oleh sebab itu kajian efektivitas ekstrak tanaman sereh wangi sebagai bahan insektisida pada cagar budaya berbahan kertas perlu dilakukan dengan tujuan untuk mengetahui efektivitas minyak atsiri sereh wangi dalam pencegahan dan mematikan serangan serangga pada cagar budaya berbahan kertas. Koleksi arsip kertas yang dimiliki diharapkan dapat terhindar dari serangan serangga dengan adanya aplikasi bahan tersebut. 


\section{Tujuan}

Tujuan dari Kajian Efektivitas Ekstrak Tanaman Sereh Wangi Sebagai Bahan Insektisida Pada Cagar Budaya Berbahan Kertas ini adalah untuk mengetahui efektivitas minyak atsiri sereh wangi dalam mencegah ataupun mematikan serangan insek/serangga yang menyerang cagar budaya kertas terutama arsip dokumen.

\section{Landasan Teori Kertas}

Masyarakat Mesir Kuno menggunakan papyrus sebagai media menulis. Kata papyrus ini kemudian dikenal dengan nama paper dalam Bahasa Inggris. Kertas merupakan lembaran kering yang dibuat dari serat tanaman yang biasanya berasal dari pohon yang tumbuhnya cepat. Industri modern membuat kertas dengan didahului pembuatan bubur kertas (pulp). Ada beberapa tanaman yang sering dipakai sebagai bubur kertas yaitu eukaliptus, akasia, rami, pinus dan cemara. Selulosa adalah komponen organik yang banyak terdapat dalam serat kayu. Selulosa ini merupakan komponen utama dalam industri bubur kertas. Produksi bubur kertas memerlukan proses yang tidak sederhana dan cukup sulit. Namun di masa sekarang dengan adanya kemajuan teknologi proses yang rumit tersebut dapat dilakukan dan dapat menghemat biaya produksi.

Kertas merupakan bahan yang sangat penting kegunaannya sebagai media tulis, kebutuhan seni, industri makanan serta pengembangan ilmu pengetahuan dan teknologi. Proses awal dari pembuatan kertas ini yaitu dengan menyiapkan bahan baku kayu yang terdiri dari kayu keras dan kayu lunak. Dalam pembuatan kertas ini membutuhkan bahan pelengkap dan bahan pembantu diantaranya pewarna, pelekat dan pengisi lubang halus pada kertas. Karakteritik dari kertas ditentukan dari bahan penyusun utama yang juga merupakan bahan utama kayu. Kandungan kimia terbesar dari bubur kertas adalah selulosa, hemiselulosa dan lignin. Selulosa merupakan komponen utama dari kayu dan merupakan polisakarida linier dengan rantai yang cukup panjang yang terdiri dari glukosaglukosa yang memudian berhubungan satu sama lain. Semakin banyak kandungan selulosa dalam kertas maka kualitas kertas akan lebih tinggi dibandingkan kertas yang kandungan hemiselulosa dan ligninnya tinggi. Hemiselulosa adalah polimer yang dibentuk dari monosakarida yang berbeda dengan selulosa. Jenis kayu yang berbeda memiliki komposisi hemiselulosa yang berbeda. Selama pembuatan bubur kertas, hemiselulosa bereaksi lebih cepat dengan larutan pemasak dibanding selulosa, dan bersifat hidroprofil (mudah menyerap air) yang mengakibatkan strukturnya kurang teratur. Lignin merupakan bagian yang tidak diinginkan dalam pembuatan bubur kertas karena memiliki sifat menolak air (hidrofobik) dan kaku sehingga kandungan lignin dalam bubur kertas akan menyulitkan penggilingan. Lignin dijumpai pada tanaman sebagai zat perekat yang berhubungan dengan kekuatan kayu. Adanya kandungan selulosa pada kertas membuat kertas disenangi oleh serangga sehingga banyak sekali arsip kertas yang rusak akibat serangan serangga.

Arsip pemugaran kedua Candi Borobudur yang kedua tahun 1973-1983 telah terdaftar dalam list Daftar Ingatan Dunia atau Memory of the World UNESCO sejak tanggal ditetapkan 30 Oktober 2019 bersama-sama dengan Arsip Tsunami Samudera Hindia dan Naskah Cerita Panji. Arsip pemugaran kedua Candi Borobudur menjadi begitu penting untuk dilestarikan karena memuat informasi penting mengenai kegiatan penyelamatan warisan budaya nenek moyang yang terbesar pada abad 20 yang melibatkan peran serta dari negara-negara lain di dunia.

Arsip pemugaran kedua Candi Borobudur yang tersimpan di kantor Balai Konservasi Borobudur terdiri dari foto kegiatan pemugaran berjumlah 71.851 buah, peta dan gambar arsitektural berjumlah 6.043 gambar, negatif kaca berjumlah 7.024 negatif, slide film positif berjumlah 13.512 slide, film negartif terdiri dari 65.741 film film seluloid berjumlah 21 rol dan dokumen proyek terdiri 425 folder. Beragam jenis arsip tersebut 
sekarang ini menjadi fokus perhatian untuk dikelelola dan dilestarikan serta dapat diakses oleh masyarakat umum dengan baik.

\section{Binatang Perusak Kertas}

Binatang yang sering menimbulkan kerusakan pada kertas adalah tikus dan curut dapat menghancurkan koleksi dengan cara:

- Mengigit material penimpan koleksi untuk mencegah pertumbuhan gigi mereka

- Dapat menyebabkan kebakaran apabila banak kabel terbuka akibat gigitan mereka

- Kotorannya dapat menyebabkan korosi dan noda pada koleksi

- Merusak kumpulan koleksi kertas sebagai sarang

Tikus dan curut merupakan salah satu jenis binatang yang sangat pintar dalam mencari makanan, apabila terjadi gangguan terhadap dirinya atau temannya maka mereka tidak akan mengulangi hal yang sama. Maka pembasmiannya tidak dapat diilakukan dengan model yang sama pada waktu yang sama melainkan menerapkan banyak alternatif seperti perangkap tikus, racun makanan, kapur barus, fumigasi. Jenis serangga yang biasa menimbulkan kerusakan pada kertas yaitu kutu buku, kecoa, rayap dan ngengat.

Serangga di atas memakan material organik seperti kertas, lem kanji, kulit, gelatin, sampul buku sebagai sumber karbohidrat yang dirubah menjadi glukosa. Hal yang terpenting dalam pengendalian serangga dan binatang adalah tindakan pencegahan dengan menjaga lingkungan yang ideal, bersih, dingin, kering, ventilasi yang baik, tidak menimbulkan adanya makanan dan tempat bersarang.

\section{Tanaman Sereh Wangi}

Tanaman sereh wangi banyak terdapat di wilayah Indonesia. Tanaman ini secara umum digolongkan menjadi dua yaitu sereh lemon atau sereh dapur (Combopogon citratus) dan sereh wangi atau sereh sitronella (Cymbopogon nardus). Di Indonesia jenis sereh wangi ada dua yaitu mahapengiri dan jenis lenabatu. Mahapengiri dapat dikenal dari bentuk daunnya yang lebih pendek dan lebih luas dari pada daun lenabatu. Hasil destilasi, jenis mahapengiri memberikan hasil minyak yang lebih tinggi dan kualitas yang lebih baik dibandingkan dengan lenabatu (Haldoko, L.A., dkk, 2014).

Sereh wangi merupakan salah satu jenis tanaman penghasil minyak atsiri. Hasil penyulingan daunnya, diperoleh minyak sereh wangi yang dalam dunia perdagangan dekenal dengan nama Citronella oil. Minyak sereh wangi Indonesia dalam pasaran terkenal dengan nama Java Citronella Oil. Komponen kimia minyak sereh wangi cukup kompleks. Senyawa utama penyusun minyak sereh wangi adalah sitronelal, sitronelol dan geraniol. Ketiga komponen ini menentukan intensitas bau harum, nilai dan harga minyak sereh wangi. Sitronelal dan geraniol merupakan bahan aktif yang tidak disukai dan sangat dihindari oleh serangga.

Beberapa penelitian mengenai ekstrak sereh wangi telah dilakukan dalam upaya sebagai bahan insektisida atau mencegah serangan serangga. Tahun 2014, Leliek dkk melakukan kajian konservasi kayu dengan menggunakan bahan tradisional berupa minyak atsiri lada hitam dan sereh wangi untuk mencegah serangan rayap dan jamur. Percobaan ini merupakan percobaan eksperimental. Untuk percobaan rayap digunakan kertas saring sedangkan untuk percobaan jamur digunakan kayu lunak yang diolesi minyak atsiri dengan konsentrasi $1 \%, 2 \%$ dan $3 \%$ dengan pelarut alkohol. Dari hasil percobaan laboratorium dihasilkan bahwa minyak atsiri sereh wangi dan lada hitam efektif untuk menangkal serangan rayap. Percobaan jamur mendapatkan hasil bahwa minyak atsiri sereh wangi efektif untuk menghambat serangan jamur sedangkan minyak atsiri lada hitam tidak efektif. Semakin tinggi konsentrasi minyak atsiri sereh wangi dan lada hitam maka semakin efektif untuk menghambat serangan rayap maupun jamur. 
Tahun 2019 ini dilakukan kajian dalam rangka pelestarian arsip MoW terutama arsip dokumen terhadap serangan serangga yang sering merusak dokumen kertas. Diharapkan dari kajian ini dihasilkan metode dan cara mencegah serangan serangga terhadap arsip dokumen dengan menggunakan bahan-bahan alami yaitu minyak atsiri sereh wangi.

\section{METODE}

\section{Alat dan Bahan}

Alat dan bahan yang dipakai dalam percobaan laboratoium dan lapangan adalah sebagai berikut: Toples/ kontainer box, Aquarium, Botol minyak atsiri, Alat tulis, Colorimeter, Kertas dokumen, Pinset, Sarung tangan, Batang pengaduk.

Bahan : Minyak atsiri sereh wangi, Serangga uji rayap kayu kering, Gelas plastic, Kertas whatman, Kertas manila hitam.

\section{Cara Kerja}

Obyek dokumen yang akan dilindungi agar tidak terkena secara langsung bahan insektisida maka metode percobaan yang dilakukan adalah dengan cara aroma atau bau dari bahan minyak atsiri yang digunakan. Metode aroma/bau atau penguapan ini bertujuan agar mencegah obyek dokumen kertas terkena langsung oleh bahan insektisida sehingga dapat menimbulkan kerusakan pada dokumen/arsip.

\section{Uji efektivitas minyak sereh wangi terhadap serangga uji}

Metode percobaan yang digunakan adalah dengan aroma/bau maka untuk menguji efektivitas minyak atsiri sereh wangi terhadap serangga perusak kertas ini tidak langsung diaplikasikan pada obyek dokumen namun seperti pewangi ruangan.

- Penelitian ini bersifat eksperimental yang bertujuan untuk mengetahui pengaruh pemberian minyak atsiri sereh wangi sebagai pengusir terhadap hewan uji yaitu rayap kayu kering. Sampel kajian sebanyak 10 ekor ekor rayap kayu kering dengan dengan tiga kali pengulangan. Prosedur kajian sebagai berikut:

a. Mempersiapkan botol yang berisi minyak atsiri sereh wangi (Cymbopogon nardus) dengan konsentrasi $100 \%$ dengan volume $25 \mathrm{ml}$.

b. Mempersiapkan perlakuan terhadap 10 ekor rayap kayu kering dengan tiga kali pengulangan dalam aquarium yang didesaik khusus sebagai percobaan pengusir rayap kayu kering. Aqurium tersebut memiliki lubang kecil sebagai jalan keluar rayap yang menghindari bau/aroma dari minakatsiri sereh wangi. Aquarium ditutup dengan rapat dan dibuat gelap. Diamkan selama 15 hari kemudian diamati setiap hari dengan mengamati/menghitung jumlah rayap kayu kering yang keluar dari ruang aquarium untuk menghindari bau/aroma minyak atsiri sereh wangi dan mencatat hasilnya.

c. Aquarium yang digunakan berjumlah 4 buah yaitu:

- kontrol, aquarium berisi hewan uji rayap kayu kering tanpa minyak atsiri sereh wangi

- berisi 1 botol, aquarium berisi hewan uji rayap kayu kering dengan minyak atsiri sereh wangi $100 \%$ sebanyak 1 botol

- berisi 2 botol, aquarium berisi hewan uji rayap kayu kering dengan minyak atsiri sereh wangi $100 \%$ sebanyak 2 botol

- berisi 3 botol, aquarium berisi hewan uji rayap kayu kering dengan minyak atsiri sereh wangi $100 \%$ sebanyak 3 botol

- Kajian ini bersifat eksperimental yang bertujuan untuk mengetahui pengaruh pemberian minyak atsiri sereh wangi sebagai insektisida/pembunuh terhadap 
hewan uji yaitu rayap kayu kering. Sampel kajian sebanyak 10 ekor ekor rayap kayu kering dengan tiga kali pengulangan. Prosedur kajian sebagai berikut:

a. Mempersiapkan botol yang berisi minyak atsiri sereh wangi (Cymbopogon nardus) dengan konsentrasi $100 \%$ dengan volume $25 \mathrm{ml}$.

b. Mempersiapkan perlakuan terhadap 10 ekor rayap kayu kering dengan tiga kali pengulangan dalam kontainer box besar berwarna gelap. Kemudian ditutup dengan tetap terdapat sedikit sirkulasi udara. Diamkan selama 15 hari kemudian diamati setiap hari dengan menghitung jumlah rayap kayu kering yang mati (mortalitas rayap) dan mencatat hasilnya.

c. Kontainer box yang digunakan berjumlah 4 buah yaitu:

- kontrol, kontainer box berisi hewan uji rayap kayu kering tanpa minyak atsiri sereh wangi

- berisi 1 botol, kontainer box berisi hewan uji rayap kayu kering dengan minyak atsiri sereh wangi $100 \%$ sebanyak 1 botol

- berisi 2 botol, kontainer box berisi hewan uji rayap kayu kering dengan minyak atsiri sereh wangi $100 \%$ sebanyak 2 botol

- berisi 3 botol, kontainer box berisi hewan uji rayap kayu kering dengan minyak atsiri sereh wangi $100 \%$ sebanyak 3 botol

\section{Uji efektivitas minyak sereh wangi terhadap cagar budaya kertas}

Kajian ini bersifat eksperimental yang bertujuan untuk mengetahui pengaruh pemberian minyak atsiri sereh wangi terhadap kondisi cagar budaya kertas.

a. Mempersiapkan ekstrak sereh wangi (Cymbopogon nardus) dengan konsentrasi $100 \%$.

b. Meletakkan dokumen kertas sebagai bahan uji dan minyak atsiri sereh wangi dalam kontainer box yang berisi 1 botol, 2 botol dan 3 botol minyak atsiri sereh wangi $100 \%$.

c. Melakukan pengukuran masing-masing kertas/dokumen uji dengan alat colorimeter sebelum dan sesudah percobaan.

Percobaan dilakukan selama waktu 15 hari dan melakukan pengamatan serta pencatatan hasil pengamatan ada tidaknya pengaruh minyak atsiri terhadap dokumen kertas dengan menggunakan colorimeter.

\section{HASIL PENELITIAN}

\section{Pengaruh minyak atsiri sereh wangi sebagai bahan mengusir serangga}

Dalam melakukan kajian dalam rangka melihat pengaruh minyak atsiri sereh wangi sebagai bahan pengusir serangga perusak kertas yaitu rayap kayu kering adalah dengan melakukan percobaan dengan meletakkan masing-masing 10 ekor rayap kayu kering di dalam 3 ruangan dalam aquarium yang berjumlah 4 buah aquarium. Keempat aquarium tersebut adalah yang pertama sebagai kontrol yaitu hanya berisi hewan uji rayap saja tanpa adanya minyak atsiri sereh wangi, aquarium kedua berisi hewan uji dan 1 botol minyak atsiri sereh wangi 100\% dengan volume $25 \mathrm{ml}$, aquarium ketiga berisi hewan uji dan 2 botol minyak atsiri sereh wangi $100 \%$ dengan volume $25 \mathrm{ml}$ dan aquarium keempat berisi hewan uji dan 3 botol minyak atsiri sereh wangi 100\% dengan volume $25 \mathrm{ml}$.

Pengamatan yang dilakukan adalah jumlah rayap yang keluar dari ruangan aquarium yang terpengaruh bau/aroma minyak atsiri sereh wangi menuju ruangan yang tidak berbau sereh wangi. Dari seluruh populasi 30 ekor rayap diamati jumlah rayap yang keluar melalui lubang untuk menghindari aroma minyak atsiri sereh wangi. Hasil pengamatan sebagai berikut. 
Tabel 1. Jumlah Rata-rata Rayap Kayu Kering yang Keluar

\begin{tabular}{ccccc}
\hline \multirow{2}{*}{ Hari } & \multicolumn{4}{c}{ Konsentrasi (mg/l) } \\
\cline { 2 - 5 } & Kontrol & $\mathbf{8 5 , 8 8 6 7}$ & $\mathbf{1 5 6 , 6 6 6 7}$ & $\mathbf{3 2 4 , 7 8 6 7}$ \\
\hline $\mathbf{1}$ & 0 & 3 & 3 & 3 \\
$\mathbf{2}$ & 0 & 5 & 4 & 4 \\
$\mathbf{3}$ & 0 & 5 & 4 & 4 \\
$\mathbf{4}$ & 0 & 5 & 4 & 4 \\
$\mathbf{5}$ & 0 & 6 & 6 & 4 \\
$\mathbf{6}$ & 0 & 8 & 6 & 4 \\
$\mathbf{7}$ & 0 & 9 & 6 & 6 \\
$\mathbf{8}$ & 0 & 12 & 7 & 6 \\
$\mathbf{9}$ & 0 & 13 & 8 & 7 \\
$\mathbf{1 0}$ & 0 & 16 & 9 & 7 \\
$\mathbf{1 1}$ & 0 & 16 & 9 & 7 \\
$\mathbf{1 2}$ & 0 & 16 & 9 & 7 \\
\hline $\mathbf{1 3}$ & 0 & 16 & 9 & 7 \\
$\mathbf{1 4}$ & 0 & 16 & 9 & 7 \\
$\mathbf{1 5}$ & 0 & 17 & 12 & 8 \\
\hline
\end{tabular}

Dari tabel di atas terlihar bahwa untuk konsentrasi $85,9 \mathrm{mg} / \mathrm{l}$ sudah bisa sebagai pengusir rayap kayu kering. Selama 15 hari pengamatan terlihat jumlah rayap yang keluar mencapai 17 ekor dari 30 populasi rayap kayu kering. Semakin tinggi konsentrasi minyak atsiri sereh wangi tidak menunjukkan perbandingan lurus dengan rayap yang keluar. Oleh karena itu konsentrasi 85,9 mg/l merupakan konsentrasi yang paling efektif untuk mengusir rayap kayu kering. Dari tabel di atas juga terlhat bahwa pada kontrol tidak terdapat satu ekor rayap yang keluar dan dari pengamatan semuanya hidup. Hal ini menunjukkan bahwa rayap yang berada di ruang aquarium tesebut dapat hidup tanpa gangguan lingkungan. Apabila dilihat dari grafik diatas, konsentrasi 85,9 ml/l efektif mengusir rayap kayu kering maksimal di hari ke 10 sudah bisa mengusir rayap sebanyak 16 ekor.

\section{Pengaruh minyak atsiri sereh wangi sebagai bahan insektisida serangga}

Dalam melakukan kajian dalam rangka melihat pengaruh minyak atsiri sereh wangi sebagai bahan insektisida atau pembunuh serangga perusak kertas yaitu rayap kayu kering adalah dengan melakukan percobaan dengan meletakkan 3 buah gelas plastik yang berisi masing-masing 10 ekor rayap kayu kering di dalam kontainer box yang berjumlah 4 buah. Masing-masing kontainer box adalah yang pertama sebagai kontrol yaitu hanya berisi hewan uji rayap saja tanpa adanya minyak atsiri sereh wangi, kontainer box kedua berisi hewan uji dan 1 botol minyak atsiri sereh wangi 100\% dengan volume $25 \mathrm{ml}$, kontainer box ketiga berisi hewan uji dan 2 botol minyak atsiri sereh wangi 100\% dengan volume $25 \mathrm{ml}$ dan kontainer box keempat berisi hewan uji dan 3 botol minyak atsiri sereh wangi $100 \%$ dengan volume $25 \mathrm{ml}$.

Pada percobaan sebelumnya telah diuji minyak atsiri sereh wangi dengan berbagai konsentrasi yaitu $1 \%$, $2 \%$ dan $3 \%$. Setelah dilakukan pengamatan selama kurang lebih 7 hari tidak menunjukkan pengaruh terhadap hewan uji rayap kayu kering. Kemudian dalam percobaan selanjutnya konsentrasi dari minyak atsiri sereh wangi ditingkatkan menjadi 5\%, 
$10 \%$ dan 15\%. Pengamatan dilakukan selama kurang lebih 7 hari. Dari hasil pengamatan ternyata di konsentrasi tersebut belum menunjukkan pengaruh terhadap hewan uji rayap kayu kering. Dalam percobaan tersebut pengamatan dilakukan dalam 5 buah kontainer box, yang pertama kontol yaitu berisi hewan uji rayap tanpa minyak atsiri serreh wangi, kontainer box kedua berisi hewan uji dan blanko yaitu botol berisi pelarut minyak atsiri sereh wangi yaitu alkohol. 3 kontainer box lainnya berisi hewan uji dan minak atsiri sereh wangi dengan berbagai konsentasi. Berdasarkan pengamatan setelah beberapa waktu botol yang berisi alkohol lebih cepat habis/menguap dibandingkan dengan minyak atsiri sereh wangi dengan berbagai konsentrasi (baik yang 1\%, 2\%, 3\% maupun yang 5\%, 10\%, 15\%). Semakin tinggi konsentrasi semakin lama menguapnya. Sehingga dapat disimpulkan bahwa tingkat penguapan alkohol dan minyak atsiri sereh wangi berbeda. hal ini menyebabkan kondisi udara di dalam kontainer box tidak sesuai dengan variasi konsentrasi sereh wangi. Oleh karena itu percobaan selanjutnya menggunakan minyak atsiri sereh wangi dengan konsentrasi $100 \%$.

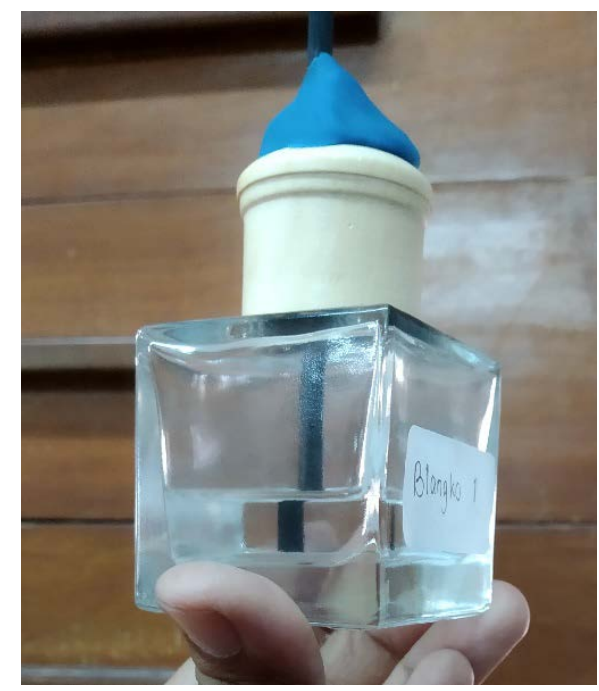

Gambar 2. Botol minyak atiri sereh wangi

Pengamatan percobaan minyak atsiri sereh wangi dengan konsentrasi $100 \%$ dilakukan selama 15 hari dengan populasi hewan uji 10 ekor rayap dengan 3 kali pengulangan. Hasilnya tampak pada tabel dan grafik mortalitas rayap di bawah. Pada tabel dan grafik yang disajikan tersebut, konsentrasi minyak atsiri sereh wangi sudah dihitung berdasarkan jumlah penguapan per volume ruang uji dalam mg/l (miligram per liter) tidak lagi dalam botol.

Tabel 1. Rata-Rata Mortalitas Rayap

\begin{tabular}{ccccc}
\hline \multirow{2}{*}{ Hari } & \multicolumn{4}{c}{ Konsentrasi (mg/l) } \\
\cline { 2 - 5 } & Kontrol & $\mathbf{3 4 , 1 0 1 4}$ & $\mathbf{6 8 , 5 4 5 7}$ & $\mathbf{1 1 1 , 5 9 7 1}$ \\
\hline $\mathbf{1}$ & 0 & 0 & 0 & 0 \\
$\mathbf{2}$ & 0 & 0 & 0 & 0 \\
$\mathbf{3}$ & 0 & 0 & 1 & 2 \\
$\mathbf{4}$ & 0 & 0 & 1 & 3 \\
$\mathbf{5}$ & 0 & 0 & 1 & 3 \\
$\mathbf{6}$ & 0 & 0 & 2 & 4
\end{tabular}




\begin{tabular}{llllll}
$\mathbf{7}$ & 0 & 0 & 2 & 4 \\
$\mathbf{8}$ & 0 & 0 & 2 & 4 \\
$\mathbf{9}$ & 0 & 1 & 3 & 5 \\
10 & 1 & 1 & 2 & 6 \\
11 & 1 & 1 & 2 & 6 \\
12 & 1 & 1 & 3 & 6 \\
13 & 1 & 1 & 4 & 7 \\
14 & 1 & 1 & 4 & 7 \\
\hline
\end{tabular}

Berdasarkan hasil percobaan selama 15 hari terlihat bahwa semakin tinggi konsentrasi minyak atsiri sereh wangi semakin tinggi mortalitas (kematian) rayap kayu kering. Dalam konsentrasi $111,6 \mathrm{ml} / \mathrm{l}$ minyak atsiri sereh wangi dapat membunuh atau mematikan rata-rata 8 ekor rayap kayu kering. Tabel hasil pengamatan selengkapnya terdapat dalam lampiran.

Efektifitas minyak atsiri sereh wangi sebagai bahan insektisida untuk membunuh rayap dinyatakan dengan LC 50. Lethal Concentration 50 (LC 50) merupakan konsentrasi bahan uji yang menyebabkan kematian sebanyak 50\% hewan uji. Uji LC 50 pada percobaan ini bertujuan untuk menentukan konsentrasi konsentrasi minyak atsiri sereh terhadap 50\% mortalitas rayap kayu kering sebagai hewan uji pada cagar budaya berbahan kertas. Berikut ini disajikan tabel perhitungan LC 50.

Tabel 2. Tabel Perhitungan LC50, percobaan selama 15 hari

\begin{tabular}{|c|c|c|c|c|c|c|c|c|}
\hline $\begin{array}{l}\text { Konsentrasi } \\
\text { (mg/l) }\end{array}$ & $\begin{array}{c}\log 10 \\
\text { konsentrasi }\end{array}$ & Ulangan & $\begin{array}{l}\text { Total } \\
\text { Rayap }\end{array}$ & $\begin{array}{c}\text { Jumlah } \\
\text { Rayap } \\
\text { Mati }\end{array}$ & $\begin{array}{c}\% \\
\text { mortalitas }\end{array}$ & $\begin{array}{c}\% \\
\text { mortalitas } \\
\text { terkoreksi }\end{array}$ & $\begin{array}{c}\text { Rerata } \\
\text { Mortalitas } \\
\text { terkoreksi } \\
\end{array}$ & $\begin{array}{l}\text { Nilai } \\
\text { Probit }\end{array}$ \\
\hline \multirow{3}{*}{0} & \multirow{3}{*}{0} & 1 & 10 & 2 & 20 & - & \multirow{3}{*}{ - } & \multirow{3}{*}{0} \\
\hline & & 2 & 10 & 1 & 10 & - & & \\
\hline & & 3 & 10 & 4 & 40 & - & & \\
\hline \multirow{3}{*}{34,1014} & \multirow{3}{*}{1,53} & 1 & 10 & 1 & 10 & -10 & \multirow{3}{*}{-10} & \multirow{3}{*}{0} \\
\hline & & 2 & 10 & 2 & 20 & 10 & & \\
\hline & & 3 & 10 & 1 & 10 & -31 & & \\
\hline \multirow{3}{*}{68,5457} & \multirow{3}{*}{1,84} & 1 & 10 & 6 & 60 & 41 & \multirow{3}{*}{34} & \multirow{3}{*}{4,59} \\
\hline & & 2 & 10 & 2 & 20 & 10 & & \\
\hline & & 3 & 10 & 9 & 90 & 52 & & \\
\hline \multirow{3}{*}{111,5971} & \multirow{3}{*}{2,05} & 1 & 10 & 6 & 60 & 41 & \multirow{3}{*}{54} & \multirow{3}{*}{5,1} \\
\hline & & 2 & 10 & 10 & 100 & 91 & & \\
\hline & & 3 & 10 & 7 & 70 & 31 & & \\
\hline
\end{tabular}




\begin{tabular}{cc}
\hline $\mathbf{0}$ & 0 \\
$\mathbf{1 , 8 4}$ & 4,59 \\
$\mathbf{2 , 0 5}$ & 5,1 \\
\hline
\end{tabular}

Untuk mencari nilai probit (probability unit) menggunakan table berkut ini:

Tabel 3. Tabel Transformasi persentase ke probits (probability units)

Table 3.2 Transformation of percentages to probits

\begin{tabular}{rcccccccccc}
\hline$\%$ & 0 & 1 & 2 & 3 & 4 & 5 & 6 & 7 & 8 & 9 \\
\hline 0 & - & 2.67 & 2.95 & 3.12 & 3.25 & 3.30 & 3.45 & 3.52 & 3.59 & 3.60 \\
10 & 3.72 & 3.77 & 3.82 & 3.87 & 3.02 & 3.06 & 4.01 & 4.05 & 4.08 & 4.12 \\
20 & 4.16 & 4.19 & 4.23 & 4.26 & 4.29 & 4.33 & 4.30 & 4.39 & 4.42 & 4.45 \\
30 & 4.48 & 4.60 & 4.63 & 4.50 & 4.69 & 4.61 & 4.64 & 4.67 & 4.69 & 4.72 \\
40 & 4.76 & 4.77 & 4.80 & 4.82 & 4.85 & 4.87 & 4.90 & 4.92 & 4.95 & 4.97 \\
50 & 5.00 & 5.03 & 5.05 & 5.08 & 5.10 & 5.13 & 5.15 & 5.18 & 5.20 & 5.23 \\
60 & 5.25 & 5.28 & 5.31 & 5.33 & 5.36 & 5.39 & 5.41 & 5.44 & 5.47 & 5.50 \\
70 & 5.52 & 5.55 & 5.68 & 5.61 & 5.64 & 5.67 & 5.71 & 5.74 & 5.77 & 5.81 \\
80 & 5.84 & 5.88 & 5.92 & 5.95 & 5.99 & 6.04 & 6.08 & 6.13 & 6.18 & 6.23 \\
90 & 6.28 & 0.34 & 0.41 & 6.48 & 6.65 & 6.64 & 6.75 & $\mathbf{0 . 8 8}$ & 7.05 & 7.33 \\
- & 0.0 & 0.1 & 0.2 & 0.3 & 0.4 & 0.5 & 0.6 & 0.7 & 0.8 & 0.9 \\
99 & 7.33 & 7.37 & 7.41 & 7.40 & 7.61 & 7.68 & 7.05 & 7.75 & 7.88 & 8.09 \\
\hline
\end{tabular}

Sumber: http://nurulfahmikesling.blogspot.com/2016/08/makalah-lethal-concentration-50-Ic50.html

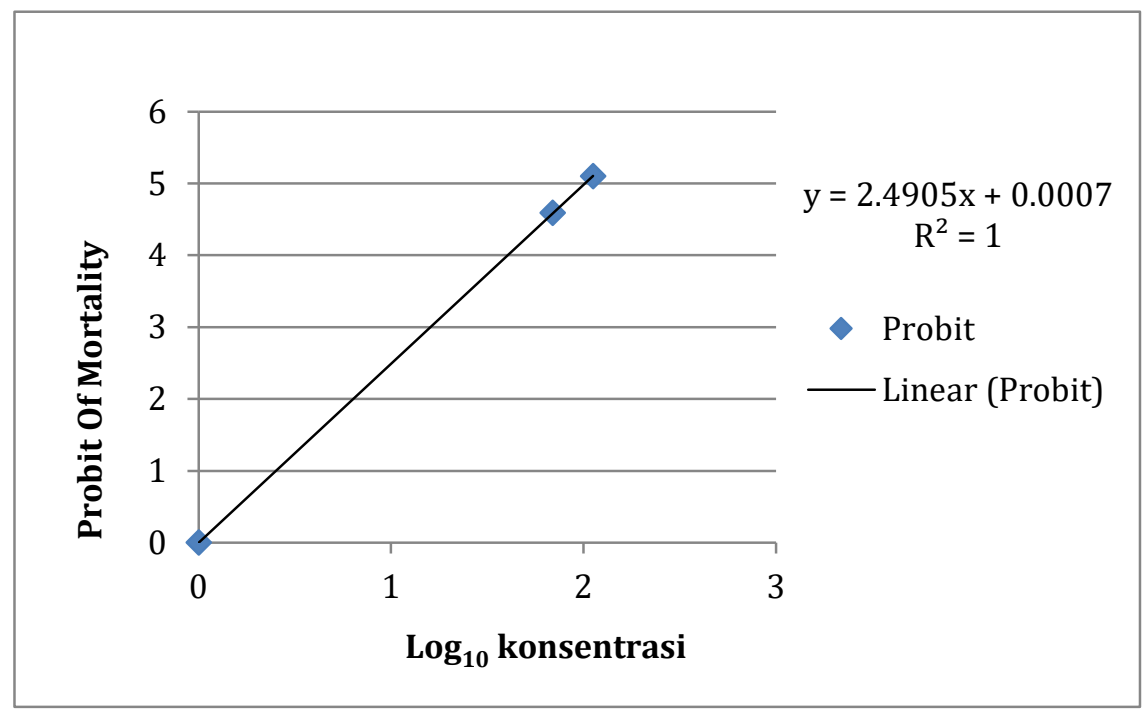

Gambar 4. Gambar grafik Probit of Mortality 
Dari grafik di atas didapatkan rumus untuk menghitung LC 50:

$\mathrm{Y}=2,4905 \mathrm{x}+0,0007$

$5=2,4905 \mathrm{x}+0,0007$

$5-0,0007=2,4905 \mathrm{x}$

$4,9993=2,4905 \mathrm{x}$

$\mathrm{X}=2,0073$

Antilog 2,0073 = 101,7

LC $50=101,7 \mathrm{mg} / \mathrm{l}$

Berdasarkan hasil perhitungan LC-50 secara penguapan dibutuhkan sebanyak $101,7 \mathrm{mg} / \mathrm{l}$ untuk membunuh 50\% dari populasi rayap kayu kering.

\section{Pengaruh minyak atsiri sereh wangi terhadap kertas dokumen}

Pengaplikasian sebuah bahan insektisida maupun pengusir serangga perusak kertas harus aman juga untuk dokumen/kertas yang ingin dilindungi. Kajian ini melakukan percobaan mengenai pengaruh minyak atsiri sereh wangi terhadap arsip dokumen kertas. Percobaan dengan cara memasukkan arsip dokumen kertas dalam kontainer box yang diisi dengan minyak atsiri sereh wangi $100 \%$ volume $25 \mathrm{ml}$ dengan berbagai variasi jumlah botol yaitu 1 botol, 2 botol dan 3 botol.

Percobaan ada tidaknya pengaruh minyak atsiri sereh wangi terhadap dokumen kertas diukur menggunakan alat colorimeter. Alat ini berfungsi untuk mengukur perubahan warna yang terjadi antara sebelum dan sesudah pengaplikasian suatu bahan pada sebuah obyek. Alat colorimeter ini mempresentasikan nilai warna dari nilai L, a dan b. L (lightness) memiliki nilai 0 - 100 dengan nilai 0 adalah warna hitam dan nilai 100 adalah warna putih, a menunjukkan warna merah/hijau, dimana nilai +a adalah warna merah dan -a adalah hijau, b menunjukkan warna kuning/biru, dimana nilai $+b$ adalah warna kuning dan -b adalah warna biru. Total perubahan warna yang terjadi dinotasikan dengan $\Delta \mathrm{E}$, apabila nilai $\Delta \mathrm{E}$ di bavah nilai 4 artinya tidak terjadi perubahan warna secara visual (Habibi, 2019). Rumus $\Delta \mathrm{E}$ sebagai berikut:

$$
\Delta E=(\Delta 2+\Delta 82+\Delta b 2) 1 / 2
$$

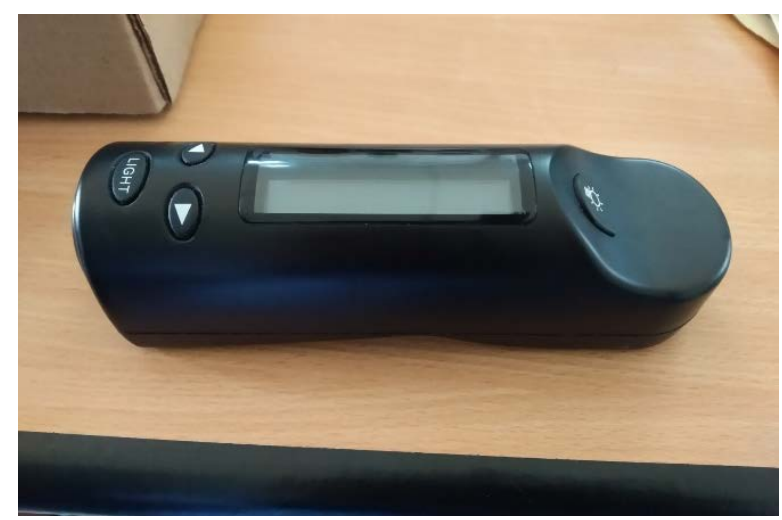

Gambar 5. Alat colorimeter 


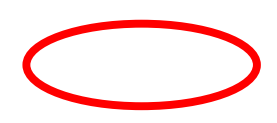

\section{Gambar 61. Aplikasi Color tool}

Dokumen kertas yang dijadikan sampel uji berasal dari Arsip Nasional Indonesia (ANRI) yang terdiri dari kertas lama, kertas conqueror dan kertas HVS. Sampel kertas diukur warnanya sebelum dan sesudah perlakukan. Setelah mendapatkan nilai L, a, b sebelum dan sesudah pengukuran, selanjutnya dimasukkan ke aplikasi Color tool yang dapat di download menggunakan handphone android untuk mendapatkan nilai $\Delta \mathrm{E}$.

Percobaan pengaruh minyak atsiri sereh wangi terhadap dokumen kertas dilakukan dengan meletakkan dokumen kertas uji ke dalam 3 buah container box yang diisi masing-masing dengan botol minyak atsiri sereh wangi 1 botol, 2 botol dan 3 botol untuk selanjutnya dihitung konsentrasi minyak atsiri tersebut berbanding volume ruang. Percobaan ini berlangsung selama 15 hari. Perhitungan konsentrasi minyak atsiri sereh wangi adalah berat awal minyak dikurangi berat akhir minyak dibagi volume ruang. Hasil perhitungan konsentrasi sebagai berikut.

Tabel 4. Hasil Perhitungan Konsentrasi Minyak Atsiri Sereh Wangi 


\begin{tabular}{ccccccc}
\hline Botol & Berat awal (gr) & $\begin{array}{c}\text { Berat akhir } \\
(\mathbf{g r})\end{array}$ & $\begin{array}{c}\text { Massa } \\
\mathbf{( g r )}\end{array}$ & $\begin{array}{c}\text { Massa } \\
(\mathbf{m g})\end{array}$ & $\begin{array}{c}\text { Volume } \\
\text { ruang (It) }\end{array}$ & $\begin{array}{c}\text { Konsentrasi } \\
(\mathbf{m g} / \mathbf{l})\end{array}$ \\
\hline $\mathbf{1 . 1}$ & 147,9574 & 146,1091 & 1,8483 & 1848,3 & 70 & 26,4043 \\
$\mathbf{2 . 1}$ & 147,836 & 144,7066 & 3,1294 & 3129,4 & 70 & 44,7057 \\
$\mathbf{2 . 2}$ & 147,3347 & 145,8759 & 1,4588 & 1458,8 & 70 & 20,8400 \\
& & & & 4588,2 & 70 & 65,5457 \\
$\mathbf{3 . 1}$ & 147,5698 & 146,2242 & 1,3456 & 1345,6 & 70 & 19,2229 \\
\hline $\mathbf{3 . 2}$ & 148,4959 & 144,3241 & 4,1718 & 4171,8 & 70 & 59,5971 \\
$\mathbf{3 . 3}$ & 147,8037 & 142,7067 & 5,097 & 5097 & 70 & 72,8143 \\
& & & & 10614,4 & 70 & 151,6343 \\
\hline
\end{tabular}

Dari tabel di atas dapat disimpulkan bahwa container box yang diisi minyak atsiri sereh wangi 1 botol memiliki konsentrasi $=26,4 \mathrm{mg} / \mathrm{l}$, yang diisi 2 botol memliki konsentrasi $=65,5 \mathrm{mg} / \mathrm{l}$ dan yang diisi 3 botol memiliki konsentrasi $=151,6 \mathrm{mg} / \mathrm{l}$.

Berikut ini kami sajikan data grafik hasil pengukuran perubahan warna $(\Delta \mathrm{E})$ pada masing masing konsentrasi.

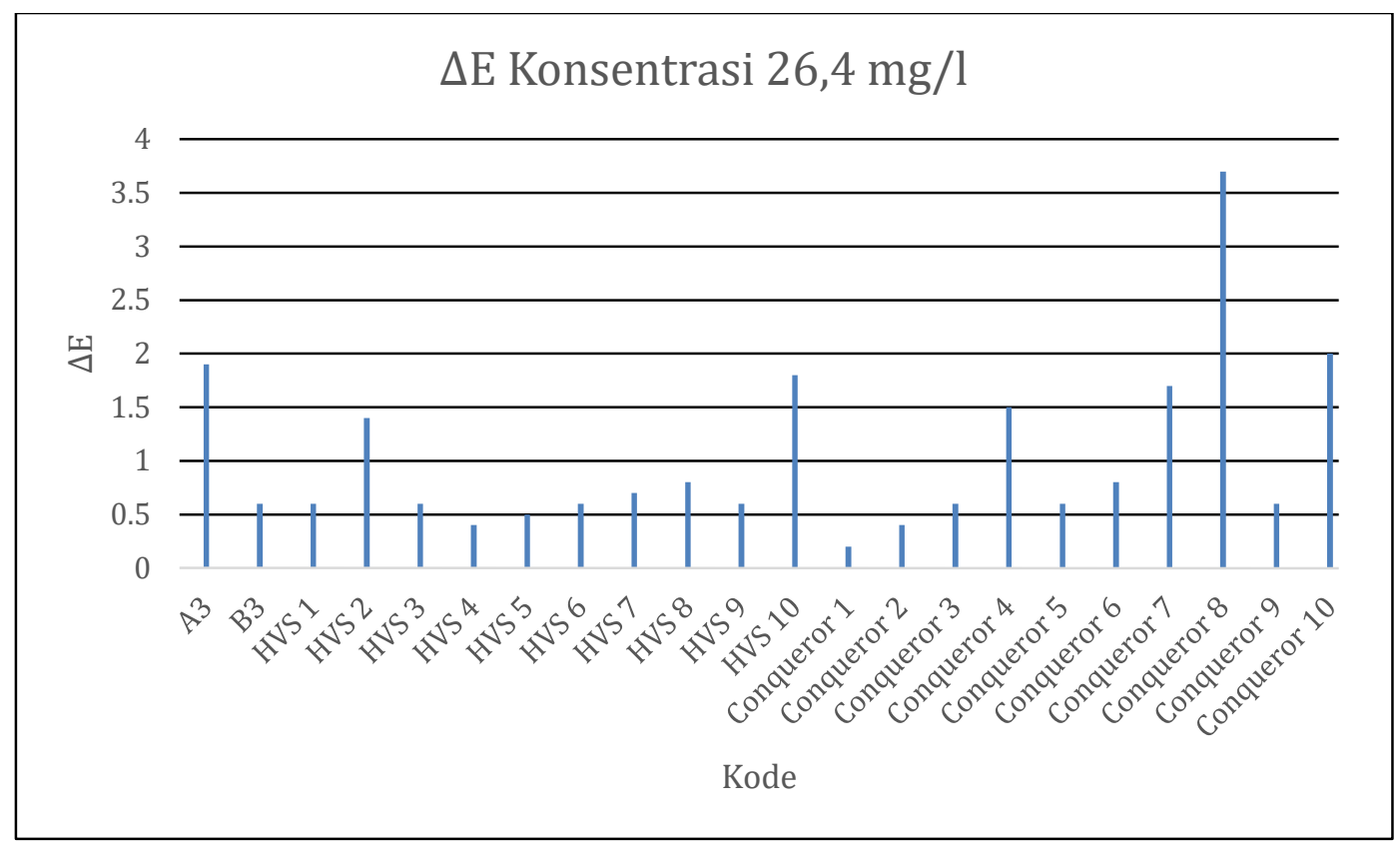

Gambar 7. Grafik perubahan warna $(\Delta \mathrm{E})$ pada konsentrasi $26,5 \mathrm{mg} / \mathrm{l}$

Berdasarkan grafik di atas terlihat bahwa minyak atsiri sereh wangi pada konsentrasi $26,4 \mathrm{mg} / \mathrm{l}$ tidak berperngaruh terhadap perubahan warna pada permukaan dokumen kertas uji. Hal ini terlihat dari nilai $\Delta \mathrm{E}$ yang lebih keil dari nilai 4 . Kertas uji terdiri dari 2 buah kertas lama (kode A3 dan B3), 10 buah kertas HVS dan 10 buah kertas conqueror. 


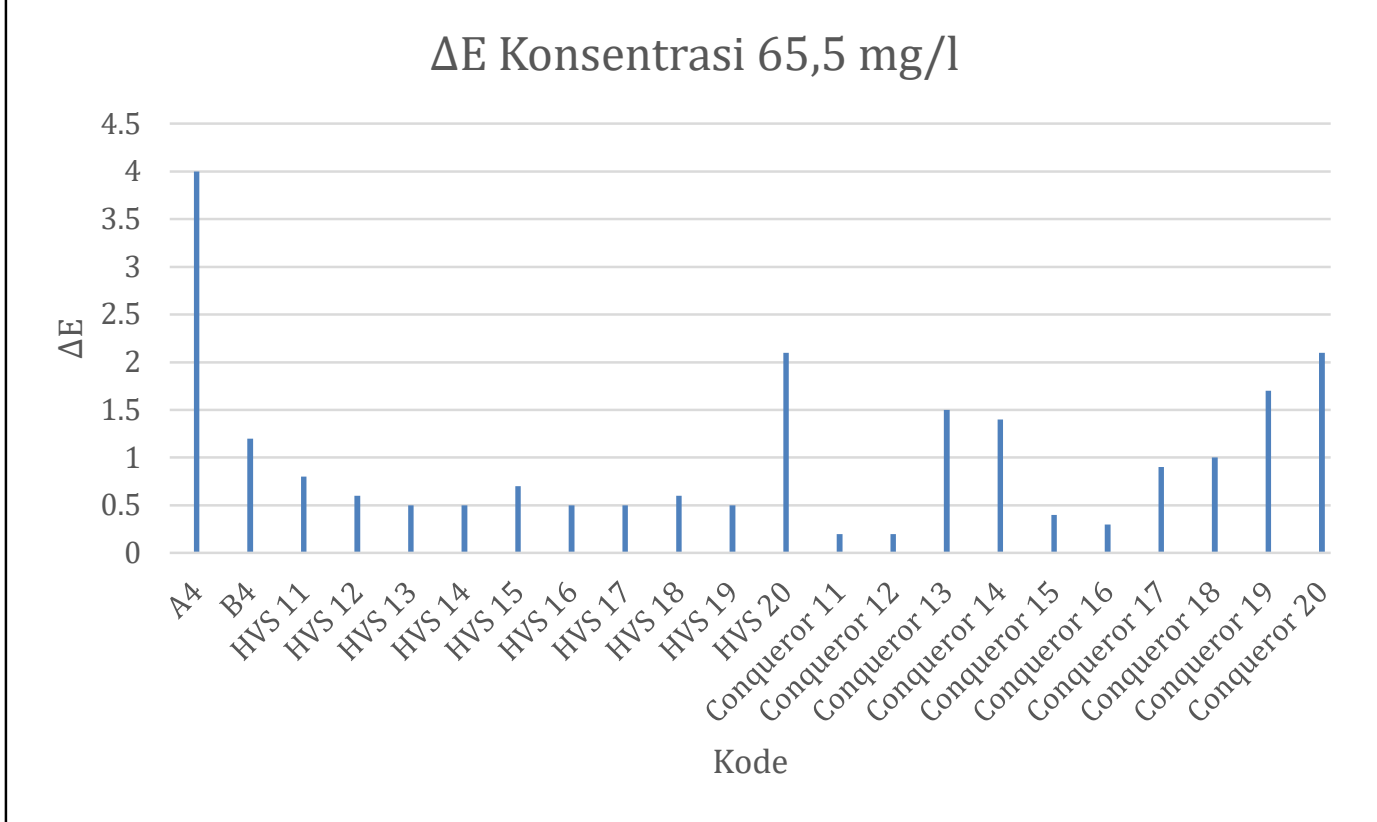

Gambar 8. Grafik perubahan warna $(\Delta \mathrm{E})$ pada konsentrasi $65,5 \mathrm{mg} / \mathrm{l}$

Berdasarkan grafik di atas terlihat bahwa minyak atsiri sereh wangi pada konsentrasi $65,5 \mathrm{mg} / \mathrm{l}$ tidak berperngaruh terhadap perubahan warna pada permukaan dokumen kertas uji. Hal ini terlihat dari nilai $\Delta \mathrm{E}$ tidak melebihi dari nilai 4. Kertas uji terdiri dari 2 buah kertas lama (kode A4 dan B4), 10 buah kertas HVS dan 10 buah kertas conqueror.

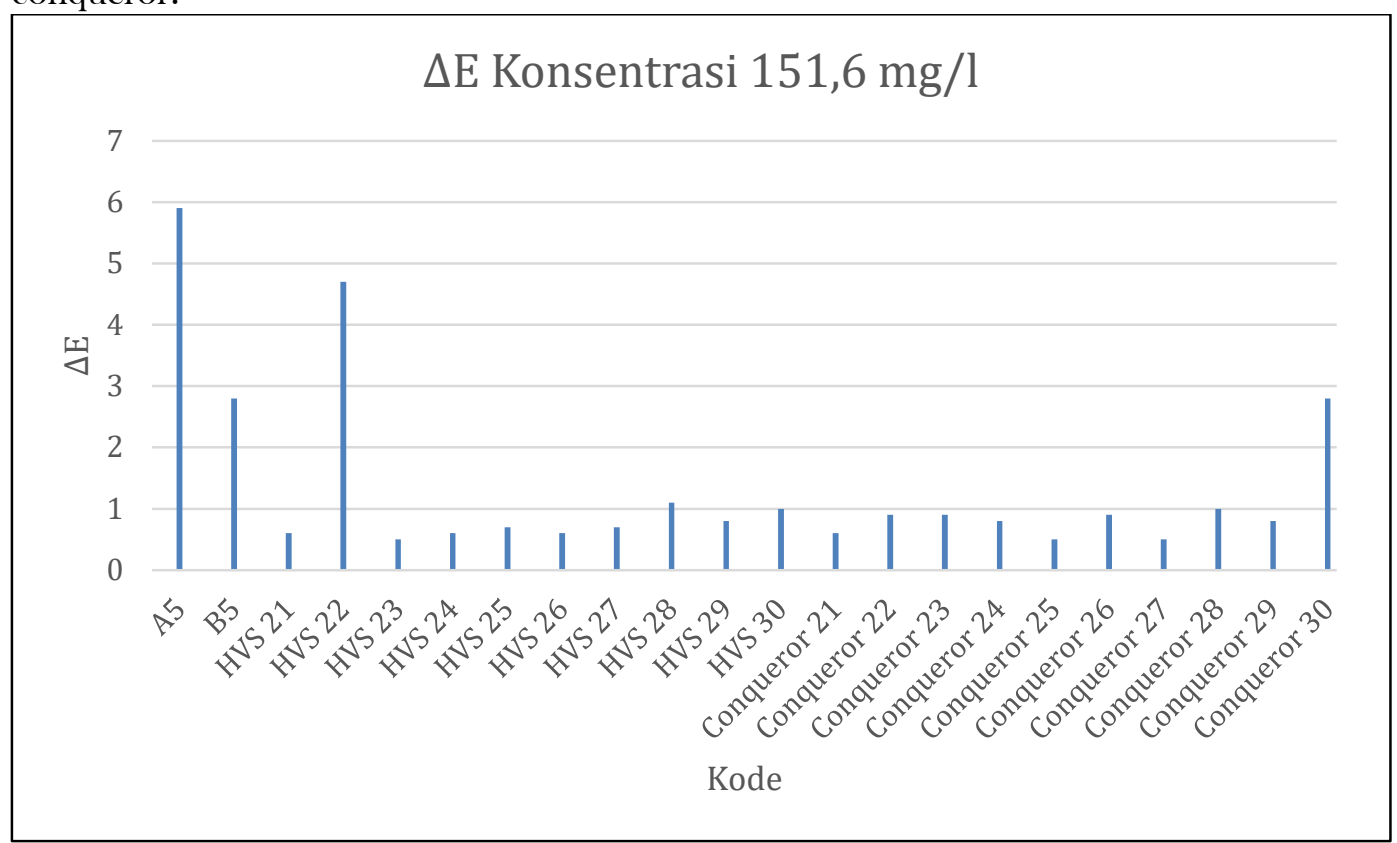

Gambar 9. Grafik perubahan warna $(\Delta \mathrm{E})$ pada konsentrasi $151,6 \mathrm{mg} / \mathrm{l}$

Berdasarkan grafik di atas terlihat bahwa minyak atsiri sereh wangi pada konsentrasi $151,6 \mathrm{mg} / \mathrm{l}$ tidak berperngaruh terhadap perubahan warna pada permukaan 
dokumen kertas uji. Obyek uji berupa kertas lama terdiri dari 2 buah (kode A5 dan B5), pada kertas A5 terlihat memliki nilai lebih dari 4 yaitu 5,9. Hal ini dikarenakan pada kertas lama permukaannya tidak merata warnanya, ada yang krem, coklat tua dan coklat tua. Pada pengukuran perbedaan warna antara sebelum dan sesudah perlakukan titik pengamatan yang diukur kemungkinan besar tidak bisa pada tempat yang sama sehingga mempengaruhi hasil pengukuran. Sedangkan kertas lama kode B5 memiliki nilai $\Delta \mathrm{E}=2,8$. Peßgukuran perbedaan warna pada kertas lama sebenarnya sangat sulit dilakukan karena warna permukaannya memang tidak merata. Untuk kertas HVS uji berjumlah 10 buah dan hanya 1 buah yang memiliki nilai di atas 4 dan rata-rata memiliki nilai di bawah 4 . Sedangkan kertas uji conqueror semuanya memiliki nilai di bawah 4. Jadi secara umum kertas uji yang diberi minyak atsiri sereh wangi konsentrasi $151,6 \mathrm{ml} / \mathrm{g}$ tidak terjadi perubahan warna secara visual.

\section{KESIMPULAN}

Dari hasil Kajian Efektivitas Ekstrak Tanaman Sereh Wangi Sebagai Bahan Insektisida Pada Cagar Budaya Kertas dapat disimpulkan hal-hal sebagai berikut:

1. Bahan minyak atsiri sereh wangi dapat berfungsi sebagai bahan pengusir dan insektisida pada hewan perusak dokumen terutama rayap kayu kering.

2. Minyak atsiri sereh wangi efektif sebagai pengusir rayap kayu kering pada konsentrasi 85,9 mg/l.

3. Efektifitas minyak atsiri sereh wangi sebagai bahan insektisida rayap kayu kering dinyatakan dengan LC 50 yaitu pada konsentrasi $101,7 \mathrm{mg} / \mathrm{l}$.

4. Tidak terdapat perubahan warna secara visual pada kertas/dokumen akibat bau/aroma minyak atsiri sereh wangi. Hal ini dapat dilihat bahwa dari hasil pengukuran perubahan warna dengan alat colori meter pada sampel kertas baik kertas arsip, HVS dan conqueror sebelum dan sesudah percobaan menggunakan minyak atsiri sereh wangi, menghasilkan $\Delta \mathrm{E}$ yang nilainya kurang dari 4 . Waktu pengamatan perubahan warna ini dilakukan selama 15 hari.

\section{SARAN}

Saran yang dapat diberikan untuk dapat dilakukan pengembangan selanjutnya dari Kajian ini adalah pembuatan bentuk dari minyak atsiri sereh wangi yang dapat diaplikasikan pada ruang storage dokumen arsip kertas sehingga aroma atau uap yang ditebarkan dapat secara merata di seluruh ruangan. 


\section{DAFTAR PUSTAKA}

Arimurti, Kamila. 2017. Efektivitas Minyak Atsiri Serai Wangi (Cymbopogon nardus) Sebagai Insektisida Alami Untuk Kecoa Amerika (Periplaneta americana). The Journal of Muhammadiyah Medical Laboratory Technologist. No.1 Vo. 2 November 2017. Universitas Muhammadiyah Surabaya

Cahyandaru, N., Parwoto dan Arif G. 2010. Konservasi Cagar Budaya Berbahan Kayu dengan Bahan Tradisional. Balai Konservasi Peninggalan Borobudur. Magelang.

Haldoko, L.A, dkk. 2014. Kajian Konservasi Kayu Dengan Bahan Tradisional. Laporan Hasil Kajian. Balai Konservasi Borobudur. Magelang

Habibi, Mohamad. 2018. Conservastion of Photographic Paper Collections Using Essential Oils. National Research Institute of Cultural Heritage. Republic of Korea

Mardani, R., Jsami, Armin, L.Z. Pengaruh Ekstrak Serai (Andropogon Nardus L.) terhadap Kunjungan Lalat Buah. Jurnal STKIP PGRI. STKIP PGRI Sumatera Barat

Razak, Muhammadin dkk. 1995. Petunjuk Teknis Pelestarian Bahan Pustaka. Perpustakaan Nasional Republik Indonesia. Jakarta

Utami, L.B. 2004. Efektivitas Serei Wangi(Cymbopogon nardus Linn) sebagai Bio Fungisida pada pengendalian Sclerotium rolfsii sacc Penyebab Busuk Pangkal Batang Tanaman Cabai Merah (Capsicum abbuum L). Prosiding Seminar Nasional Hasil-Hasil Penelitian Tahun 2004. Universitas Muhammadiyah Semarang. 